\title{
Antioxidant activity of mushrooms in vitro and in frankfurters
}

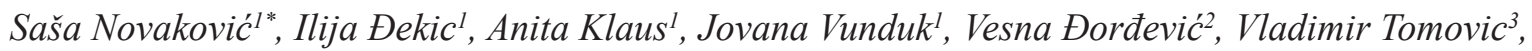 \\ Branislav Šojić3, Sunčica Kocić-Tanackov, Igor Tomaševićl
}

A b s tr a c t: The antioxidant properties of Boletus edulis, Cantharellus cibarius and Craterellus cornicupioides decoctions and the effect of mushroom addition on the total phenolic content and the degree of secondary oxidative changes on lipids in frankfurters was studied. Moderate antioxidant activity was obtained by DPPH assay when mushroom decoctions were tested in vitro. Using the conjugated diene method, moderate antioxidant activity was achieved with Boletus edulis and Craterellus cornicupioides decoction, while with Cantharellus cibarius decoction, antioxidant activity was low. Constant amounts of phenolic acid were obtained in frankfurters fortified with Boletus edulis, while lipid oxidation on each tested day was several times less than in the control group of frankfurters, throughout two months of refrigerated storage. Generally, these mushrooms could be used as natural antioxidants to interfere with the chemical deterioration of food products and specifically, to extend the shelf life of cooked pork sausages.

Keywords: Antioxidant, Natural extract, Shelf life, Mushroom, Phenolics.

\section{Introduction}

Emulsification technology for frankfurter-type sausage production has been used for several hundred years. Frankfurters are the most widespread type of emulsified meat product in the world (Fernández-López et al., 2019). Due to volatility of the used meat, spices and other components, effects of high temperatures in thermal treatment and different storage conditions, cooked sausages are exposed to microbiological (Sachindra et al., 2005), chemical and sensory degradation (Hayes et al., 2011).

Lipid oxidation is recognized as the major problem producing negative effects on the quality and shelf life of meat products, causing oxidative off-flavours, discoloration and spoilage of meat and meat products (Morrissey et al., 1998). Hence, there is presently increasing interest in the control of lipid oxidation in meat products by using antioxidant compounds from synthetic and natural sources (Deda et al., 2007; Özvural \& Vural, 2011). However, it is assumed that the existing synthetic antioxidants cause toxicity problems that negatively affect consumers' health, and therefore, usage of these compounds is limited in food (Botterweck et al., 2000). A new trend in partially and totally substituting these synthetic antioxidants with antioxidants from natural sources received the most attention among consumers and meat processors (Ahn et al., 2004; Deda et al., 2007; Yllmaz et al., 2002). Thus, a need for recognizing alternative safe sources of natural antioxidants, specifically of plant origin, has considerably increased in recent years (Skerget et al., 2005).

Mushrooms can be an alternative, less processed and readily available source of natural antioxidants (Djekic et al., 2017a). Drying mushrooms is beneficial, as it concentrates mushroom nutrients such as heat-stable minerals, proteins and umami mixtures. They contain various polyphenolic compounds known as excellent antioxidants (Djekic et al., 2017b) due to their capability of scavenging free radicals by single-electron transfer (Hirano et al., 2001). Therefore, the objective of this study was to investigate the antioxidative effect of Boletus edulis (BE), Cantharellus cibarius $(\mathrm{CaC})$ and Craterellus cornicupioides $(\mathrm{CrC})$ in vitro and in frankfurters, in order to examine the potential antioxidant effect of the mushrooms on lipid oxidation during the refrigerated storage of frankfurters.

${ }^{1}$ University of Belgrade, Faculty of Agriculture, Nemanjina 6, 11080 Belgrade, Republic of Serbia;

${ }^{2}$ Institute of Meat Hygiene and Technology, Kacanskog 13, Belgrade, Republic of Serbia.

${ }^{3}$ University of Novi Sad, Faculty of Technology, Bulevar cara Lazara 1, 21000 Novi Sad, Republic of Serbia.

*Corresponding author: Novaković Saša, sasa.novakovic@agrif.bg.ac.rs 


\section{Materials and Methods}

\section{Sample preparation}

In order to obtain a decoction, a mixture (1:10) of dry powdered mushroom and Milli-Q (MQ) water obtained from a Milli-Q water purification system (Merck, Darmstadt) was heated at $80^{\circ} \mathrm{C}, 1 \mathrm{~h}$. The resulting decoction was subjected to all further analyses and also, together with a solid part, it was used as a component in making frankfurters.

\section{Antioxidant capacity of mushroom decoctions in vitro}

\section{DPPH (1,1-Diphenyl-2-picrylhydrazyl) assay}

The method was performed according to Vunduk et al. (2015). Extract solutions were prepared in MQ water (Merck, Darmstadt).

\section{Lipid peroxidation}

The conjugated diene method according to Lingnert et al. (1979) was used.

\section{Preparation of frankfurters}

The decoctions of mushrooms were prepared as follows: $60 \mathrm{~g}$ of powder was added to $2 \mathrm{~L}$ of distilled water and heated at $80^{\circ} \mathrm{C}$. The mixture was subjected to reflux for $60 \mathrm{~min}$ at $80^{\circ} \mathrm{C}$. The decoctions obtained in this way were poured into a plastic container, cooled, and frozen to obtain ice. This was repeated in triplicate and added to frankfurters during production (T1). The same procedure was applied to the following batch (T2), with the exception that $120 \mathrm{~g}$ of powder was used in each individual batch. The control frankfurter formulation (C) was prepared with ice obtained from distilled water. All treatments were formulated to obtain $8 \mathrm{~kg}$ batter and each treatment was prepared in triplicate (Table 1).

To determine whether the mushroom decoctions released antioxidant activities in the frankfurters, the common spices such as onion, garlic, etc. were not added, and the sausages were not subjected to smoking, because these spices and smoke can also have antioxidant characteristics which could affect and mask the real effect of the added decoctions in the products. Fresh pork hams (Musculus Biceps femoris, M. Semitendinosus and M. Semimembranosus) and pork back fat at $48 \mathrm{~h}$ post-mortem were bought from a local abattoir. All connective tissue and visible fat were removed from the ham muscles. Lean meat and back fat were minced through an $8-\mathrm{mm}$ plate using a meat grinder (Laska $82 \mathrm{H}$, Austria). The meat was transferred to a bowl chopper (Müller EMS, Germany), and salt and polyphosphate were added. The meat was comminuted for 3 min at low speed to extract myofibrillar proteins until the temperature reached $6^{\circ} \mathrm{C}$, when other ingredients were slowly added. The temperature of the mixture was not allowed to exceed $12^{\circ} \mathrm{C}$ (Costa-Lima et al., 2014). After emulsification, meat batters were immediately stuffed into collagen casings (Edicas, Girona, Spain; approximately $22 \mathrm{~mm}$ diameter) using a stuffer. The frankfurters were cooked at $80^{\circ} \mathrm{C}$ in a smokehouse until the core temperature of $72^{\circ} \mathrm{C}$ was reached. The cooked frankfurters were cooled using a shower. Thereafter, the frankfurters were placed in vacuum bags ( 3 frankfurters/bag, all from an individual batch) (day 0). The vacuum bags containing frankfurters were then sealed with a tabletop vacuum machine, (MVS 35x, Minipack-Torre SpA, Italy) and stored at $1-4^{\circ} \mathrm{C}$. All the experiments were conducted in the pilot meat processing plant at the Animal Source Food Technology Department of the Faculty of Agriculture, University of Belgrade.

Table 1. Formulae of the different types of frankfurters (expressed as $\%$ of the different ingredients in the formulae).

\begin{tabular}{lccc}
\hline & $\mathbf{T 1}^{\mathbf{1}}$ & $\mathbf{T 2}^{\mathbf{1}}$ & $\mathbf{C}^{\mathbf{1}}$ \\
Meat & $48 \%$ & $48 \%$ & $48 \%$ \\
Fat & $25 \%$ & $25 \%$ & $25 \%$ \\
Ice & - & - & $25 \%$ \\
Decoction 1 & $25 \%$ & - & - \\
Decoction 2 & - & $25 \%$ & - \\
Sodium nitrite & $1.7 \%$ & $1.7 \%$ & $1.7 \%$ \\
Polyphosphate & $0.3 \%$ & $0.3 \%$ & $0.3 \%$
\end{tabular}

Legend: ${ }^{1} \mathrm{~T} 1$ : concentration of $0.75 \%$ mushroom in the batch. T2: concentration of $1.5 \%$ mushroom in the batch. C: control, ice instead of mushroom decoction. 


\section{Total phenolic content}

Amounts of cooked frankfurters (5 g) were homogenized and extracted with $25 \mathrm{~mL}$ of ethanol $(96 \%)$. The extraction was carried out in an Ultraturax at $15000 \mathrm{rpm}$ for $2 \mathrm{~min}$. The resulting extract was filtered through a $1-2 \mu \mathrm{m}$ filter paper. After filtration, $1 \mathrm{~mL}$ of the extract was added to a cuvette, followed by Folin-Ciocalteu reagent $(0.5 \mathrm{~mL})$ and saturated sodium carbonate solution $(1 \mathrm{~mL})$. After $1 \mathrm{~h}$, the blue dye formed was measured at a wavelength of $725 \mathrm{~nm}$ against a blank using a Jenway 6300 spectrophotometer (Jenway, Felsted, United Kingdom). The phenol content was calculated based on the calibration curve (concentration-dependent absorbance function) of the standard solution of gallic acid. The result was expressed as milligram equivalents of gallic acid per kilogram of the sample - mg GAE $\mathrm{kg}^{-1}$ (Naveena et al., 2013). As a result, the arithmetic means of the phenol content were determined in three finely ground baked frankfurters from each of the sausage batches examined.

\section{TBARs determination}

TBARs (2-thiobarbituric acid reactive substances) test was accomplished using the method of Bostoglou et al. (1994), with the following alterations. The total volume of trichloroacetic acid (TCA) was added to the sample, and extraction was performed in an ultrasonic bath XUB 12 (Grant Instruments, Cambridge, UK) (Sojic et al., 2015). A Jenway spectrophotometer 6300 (Jenway, Felsted, United Kingdom) was used to measure absorbances. TBARs analyses were performed on three frankfurters from each batch, and results were expressed as mean milligrams of malondialdehyde (MDA) per kilogram of frankfurter.

\section{Statistical analysis}

The data for phenolic content and TBARs analyses were analyzed using the mixed split plot model ANOVA procedure considering 'storage day' and 'treatment' as independent variables. Mean differences between groups were tested using Bonferroni's post hoc test operating at a 5\% level of significance. All statistical analyses were carried out using SPSS for Windows (SPSS 23.0, Chicago, IL, USA).

The data obtained from the antioxidant analyses of mushroom decoctions in vitro were processed using one-way analysis of variance (ANOVA). Tukey's HSD post hoc test was used to distinguish statistical differences between the sausages and storage $(\mathrm{p}<0.05)$.

\section{Results and Discussion}

\section{Scavenging capacity as measured by DPPH (1,1-Diphenyl-2-picrylhydrazyl) assay}

The DPPH assay, based on the measurement of the scavenging capacity of antioxidants towards the stable radical, DPPH, is one of the most common techniques for the determination of antioxidant capacity (Abdullah et al., 2012). Concentration-dependent scavenging activity was observed in all frankfurters (Table 2). Compared to the positive control used (L-ascorbic acid), mushrooms tested

Table 2. Scavenging ability of the mushroom decoctions and the commercial antioxidant, L-ascorbic acid as measured by DPPH (1,1-Diphenyl-2-picrylhydrazyl) assay.

\begin{tabular}{lcccc}
\hline Concentration $\left(\mathbf{m g ~ m L}^{-1}\right)$ & $\mathbf{B E}^{\mathbf{1}}$ & $\mathbf{C a C}^{\mathbf{1}}$ & $\mathbf{C r C}^{\mathbf{1}}$ & $\mathbf{A A}^{\mathbf{1}}$ \\
\hline 0.625 & $21.1 \pm 0.95^{\mathrm{a}, \mathrm{A}}$ & $12.72 \pm 10.02^{\mathrm{ab}, \mathrm{A}}$ & $5.36 \pm 4.38^{\mathrm{b}, \mathrm{A}}$ & $81.33 \pm 1.11^{\mathrm{c}, \mathrm{A}}$ \\
1.25 & $35.42 \pm 7.13^{\mathrm{a}, \mathrm{AB}}$ & $13.43 \pm 2.95^{\mathrm{b}, \mathrm{A}}$ & $16.48 \pm 3.85^{\mathrm{ab}, \mathrm{A}, \mathrm{B}}$ & $83.65 \pm 0.09^{\mathrm{c}, \mathrm{B}}$ \\
2.5 & $32.96 \pm 11.56^{\mathrm{a}, \mathrm{A}}$ & $20.57 \pm 1.85^{\mathrm{ab}, \mathrm{A}, \mathrm{B}}$ & $14.63 \pm 6.91^{\mathrm{b}, \mathrm{A}}$ & $83.38 \pm 0.15^{\mathrm{c}, \mathrm{B}}$ \\
5 & $43.62 \pm 15.97^{\mathrm{a}, \mathrm{AB}}$ & $26.08 \pm 9.15^{\mathrm{a}, \mathrm{B}}$ & $24.7 \pm 6.02^{\mathrm{a}, \mathrm{A}, \mathrm{B}}$ & $84.38 \pm 0.26^{\mathrm{b}, \mathrm{B}}$ \\
10 & $57.55 \pm 7.19^{\mathrm{a}, \mathrm{B}}$ & $31.2 \pm 1.1^{\mathrm{b}, \mathrm{A}}$ & $29.46 \pm 1.11^{\mathrm{b}, \mathrm{B}}$ & $81.07 \pm 0.49^{\mathrm{c}, \mathrm{A}}$ \\
$\mathrm{EC}_{50}$ & 4.46 & 7.41 & 8.65 & - \\
\hline
\end{tabular}

Legend: ${ }^{1}$ Abbreviations: $\mathrm{BE}$ - Boletus edulis; $\mathrm{CaC}$ - Cantharellus cibarius; $\mathrm{CrC}$ - Craterellus cornicupioides; AA - L-ascorbic acid; $\mathrm{EC}_{50}$ value $\left(\mathrm{mg} \mathrm{mL}^{-1}\right)$ is the effective concentration at which DPPH radicals were scavenged by $50 \%$. Notes: Values are mean \pm standard deviation. Means in the same column with different capital letters and means in the same row with different lowercase letters are significantly different $(\mathrm{p}<0.05)$ 
by this assay had significantly lower values for each concentration.

The scavenging activity of mushroom extracts towards DPPH free radicals can also be expressed in terms of $\mathrm{EC}_{50}$. The $\mathrm{EC}_{50}$ value $\left(\mathrm{mg} \mathrm{mL}^{-1}\right)$ is the effective concentration at which $50 \%$ of the DPPH radicals were scavenged and was obtained by interpolation from the linear regression analysis. $\mathrm{EC}_{50}$ values for $\mathrm{BE}, \mathrm{CaC}$ and $\mathrm{CrC}$ were 4.46, 7.41 and 8.65 , respectively. A lower $\mathrm{EC}_{50}$ value corresponds to a higher antioxidant activity of the mushroom extract. Puttaraju et al. (2006) reported $\mathrm{EC}_{50}$ values for hot water extract of $\mathrm{BE}$ and $\mathrm{CaC}$ to be 1.30 and 6.40, respectively.

We wanted to test exactly this method (decoction), due to its convenience (easy, fast, simple and cost-effective) that would mean it could later easily find its way to industrial application. Concerning $\mathrm{CrC}$, the extract used in this study $\left(8.65 \mathrm{mg} \mathrm{mL}^{-1}\right)$ had a higher antioxidant effect than the hot aqueous extract of the same mushroom, reported in the study of Liu et al. (2012) (26.37 mg mL $\left.\mathrm{m}^{-1}\right)$. The ability of hot water extract to quench free radicals has been reported by many researchers. Chirinang and Intarapichet (2009) reported strong antioxidant activity of mature and baby Ling chih (Ganoderma tsugae Murrill), with low $\mathrm{EC}_{50}$ of 0.30 and $0.40 \mathrm{mg} \mathrm{mL}^{-1}$, respectively. The same authors reported moderate antioxidant activity with the same extraction technique for Pleurotus ostreatus $\left(\mathrm{EC}_{50}=11.56 \mathrm{mg} \mathrm{mL}^{-1}\right)$ and for P. sajor-caju $\left(\mathrm{EC}_{50}=13.38 \mathrm{mg} \mathrm{mL}^{-1}\right)$. In the study of Öztürk et al. (2007), Agaricus blazei, Agrocybe cylindracea and $B$. edulis displayed moderate DPPH scavenging activities with $\mathrm{EC}_{50}$ of 13.75 , 26.98 and $15.78 \mathrm{mg} \mathrm{mL}^{-1}$, respectively. In total, the decoctions of the three mushrooms tested by DPPH assay showed moderate scavenging ability in comparison to the literature reports on other mushrooms.

\section{Lipid peroxidation as measured by the conjugated diene method}

Using the conjugated diene method, at the concentration of $10 \mathrm{mg} \mathrm{mL}^{-1}$, antioxidant activities of the decoctions were $53.94 \pm 5.27,22.36 \pm 1.34$ and $68.75 \pm 0.33 \%$ for $\mathrm{BE}, \mathrm{CaC}$ and $\mathrm{CrC}$, respectively (Table 3). Also, antioxidant activity obtained by these three mushrooms was dose-dependent, reaching their maxima at $10 \mathrm{mg} \mathrm{mL}^{-1}$. In comparison to the positive control (L-ascorbic acid), our values were significantly lower at each tested concentration.

At the same concentration, measured with the same method, Mau et al. (2005) reported antioxidant activity about $60 \%$ for Ling chih (Ganoderma tsugae Murrill) mushroom. These values correspond to the values obtained in our study for $\mathrm{BE}$ and $\mathrm{CrC}$, while the antioxidant activity we obtained from $\mathrm{CaC}$ was significantly lower (Table 3 ). Similar results for antioxidant activity at the same tested concentration for Pleurotus citrinopileatus mushroom were reported by Lee et al. (2007). In their study, Tsai et al. (2007) reported considerably higher values $(66.3 \%$, $83.0 \%$, and $85.7 \%$ for Agaricus blazei, Agrocybe cylindracea, and $B$. edulis, respectively) in comparison to our results at the same tested concentration (5 $\mathrm{mg} \mathrm{mL}^{-1}$ ).

The conjugated-diene method is based on the ability of the tested compound to slow down the oxidation of conjugated dienes, which can be formed only from polyunsaturated fatty acids (Huang et al., 2005). Since linoleic acid is used as a substrate in

Table 3. Ability of mushroom decoctions and the commercial antioxidant, L-ascorbic acid, to prevent the peroxidation of linoleic acid.

\begin{tabular}{ccccc}
\hline $\begin{array}{c}\text { Concentration of active } \\
\text { compound }\left(\mathbf{m g ~ m L}^{-1}\right)\end{array}$ & $\mathbf{B E}^{\mathbf{1}}$ & $\mathbf{C a C}^{\mathbf{1}}$ & $\mathbf{C r C}^{\mathbf{1}}$ & $\mathbf{A A}^{\mathbf{1}}$ \\
\hline 0.1 & $0 \pm 0^{\mathrm{a}, \mathrm{A}}$ & $0 \pm 0^{\mathrm{a}, \mathrm{A}}$ & $14.14 \pm 2.31^{\mathrm{b}, \mathrm{A}}$ & $78.33 \pm 0.91^{\mathrm{c}, \mathrm{A}}$ \\
1 & $0 \pm 0^{\mathrm{a}, \mathrm{A}}$ & $0 \pm 0^{\mathrm{a}, \mathrm{A}}$ & $27.52 \pm 0.18^{\mathrm{b}, \mathrm{B}}$ & $79.5 \pm 0.75^{\mathrm{c}, \mathrm{A}, \mathrm{B}}$ \\
2.5 & $15.63 \pm 1.06^{\mathrm{a}, \mathrm{B}}$ & $0 \pm 0^{\mathrm{b}, \mathrm{A}}$ & $44.07 \pm 1.32^{\mathrm{c}, \mathrm{C}}$ & $79.6 \pm 0.9^{\mathrm{d}, \mathrm{A}, \mathrm{B}}$ \\
5 & $40.79 \pm 1.97^{\mathrm{a}, \mathrm{C}}$ & $11.75 \pm 1.98^{\mathrm{b}, \mathrm{B}}$ & $62.5 \pm 1.32^{\mathrm{c}, \mathrm{D}}$ & $80.84 \pm 0.72^{\mathrm{d}, \mathrm{B}}$ \\
10 & $53.94 \pm 5.27^{\mathrm{a}, \mathrm{D}}$ & $22.36 \pm 1.34^{\mathrm{b}, \mathrm{C}}$ & $68.75 \pm 0.33^{\mathrm{c}, \mathrm{E}}$ & $82.73 \pm 0.8^{\mathrm{d}, \mathrm{C}}$ \\
\hline
\end{tabular}

Legend: ${ }^{1}$ Abbreviations: $\mathrm{BE}$ - Boletus edulis; $\mathrm{CaC}$ - Cantharellus cibarius; $\mathrm{CrC}$-Craterellus cornicupioides; $\mathrm{AA}$ - L-ascorbic acid. Notes: Values are mean \pm standard deviation. Means in the same column with different capital letters and means in the same row with different lowercase letters are significantly different $(\mathrm{p}<0.05)$ 
this assay, it is not completely the same as a biological system and forms only one type of conjugated diene. Hence, this method is not enough for the complete evaluation of the ability of an antioxidant substance to act preventively in complex systems like food. Thus, when testing the antioxidant properties of the final frankfurter products, we also used another method, more specific to meat products.

\section{Total phenolic content of frankfurters during cold storage}

The main compounds responsible for the antioxidant activity of mushrooms are phenolics ( $E l$ mastas et al., 2007). Our results showed frankfurters fortified with $\mathrm{BE}$ mushroom contained the highest amount of phenolics, while $\mathrm{CaC}$ and $\mathrm{CrC}$ frankfurters contained significantly lower levels of phenolics, on each day of examination during storage (Figure 1). Previously, researchers confirmed the relationship between total phenolic compounds and antioxidant activity was linear (Annegowda et al., 2013; Isabelle et al., 2010). Also, phenolic compounds in our frankfurters with BE mushroom remained almost unchanged during the storage, which agrees with the findings of Ribas-Agusti et al. (2014) and Van Ba et al. (2016). On the other hand, lower phenolic concentrations throughout the storage period were obtained for frankfurters prepared with extracts obtained from $\mathrm{CaC}$ and CrC. Palacios et al. (2011) reported that chlorogenic, $p$-coumaric, homogentisic and protocatechuic acids were found in B. edulis, but not in Cantharellus cibarius or Craterellus cornicupioides. Also, the same researchers reported higher amounts of gallic, gentistic and $p$-hydroxybenzoic acids in $\mathrm{BE}$ than in $\mathrm{CaC}$ and $\mathrm{CrC}$ extracts, which could explain the persistence during storage of the antioxidant compounds in our frankfurters prepared with $\mathrm{BE}$ decoction.

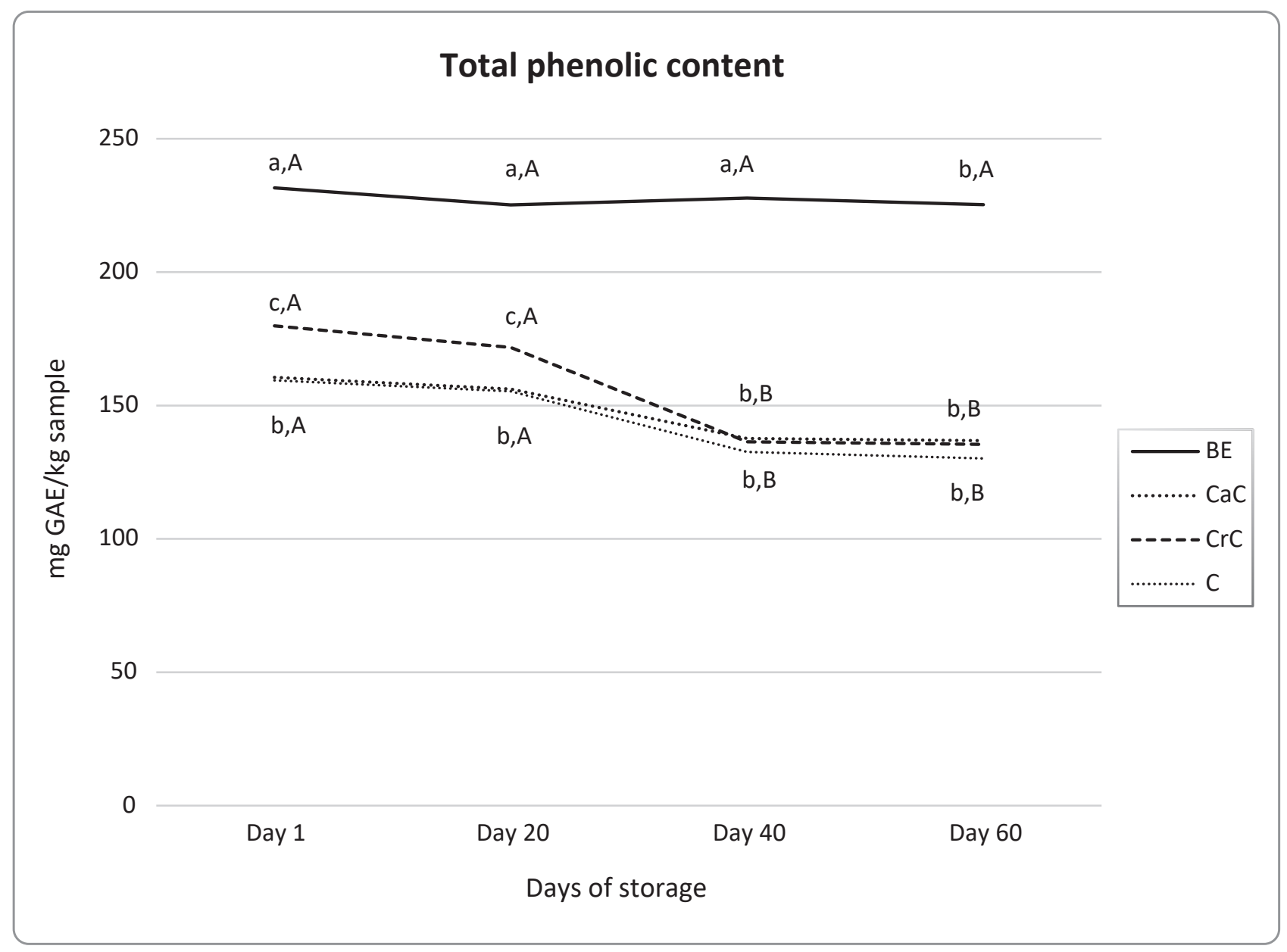

Figure 1. Total phenolic content in frankfurters, expressed as $\mathrm{mg} \mathrm{GAE} / \mathrm{kg}$ of sample.

Legend: ${ }^{1}$ Abbreviations: $\mathrm{BE}-$ Boletus edulis; $\mathrm{CaC}$-Cantharellus cibarius; $\mathrm{CrC}$-Craterellus cornicupioides; $\mathrm{C}$ - control. Values with different lowercase letters $(a-c)$ in the same column (for the different treatments) differ significantly $(\mathrm{p}<0.05)$. Values with different uppercase letters $(A-B)$ on the same line (for the same treatment at different storage time) differ significantly $(\mathrm{p}<0.05)$. 
Table 4. Thiobarbituric acid reactive substances (TBARs) values of frankfurters formulated with different mushroom decoctions during refrigerated storage.

\begin{tabular}{lcccc}
\hline Day of Storage & $\mathbf{B E}^{\mathbf{1}}$ & $\mathbf{C a C}^{\mathbf{1}}$ & $\mathbf{C r C}^{\mathbf{1}}$ & $\mathbf{C}^{\mathbf{1}}$ \\
\hline Day 1 & $0.22 \pm 0.02^{\mathrm{a}, \mathrm{A}}$ & $0.34 \pm 0.04^{\mathrm{b}, \mathrm{A}}$ & $0.14 \pm 0.02^{\mathrm{c}, \mathrm{A}}$ & $0.56 \pm 0.02^{\mathrm{d}, \mathrm{A}}$ \\
Day 10 & $0.33 \pm 0.01^{\mathrm{a}, \mathrm{B}}$ & $0.45 \pm 0.01^{\mathrm{b}, \mathrm{B}}$ & $0.31 \pm 0.02^{\mathrm{a}, \mathrm{B}}$ & $0.71 \pm 0.02^{\mathrm{c}, \mathrm{B}}$ \\
Day 20 & $0.20 \pm 0.01^{\mathrm{a}, \mathrm{A}, \mathrm{C}}$ & $0.46 \pm 0.02^{\mathrm{b}, \mathrm{B}}$ & $0.42 \pm 0.03^{\mathrm{b}, \mathrm{C}}$ & $0.59 \pm 0.02^{\mathrm{c}, \mathrm{A}, \mathrm{C}}$ \\
Day 30 & $0.17 \pm 0.01^{\mathrm{a}, \mathrm{C}, \mathrm{D}}$ & $0.19 \pm 0.01^{\mathrm{a}, \mathrm{C}}$ & $0.17 \pm 0.02^{\mathrm{a}, \mathrm{A}}$ & $0.63 \pm 0.01^{\mathrm{b}, \mathrm{C}}$ \\
Day 40 & $0.16 \pm 0.01^{\mathrm{a}, \mathrm{D}}$ & $0.15 \pm 0.01^{\mathrm{a}, \mathrm{D}}$ & $0.11 \pm 0.01^{\mathrm{a}, \mathrm{D}}$ & $0.60 \pm 0.04^{\mathrm{b}, \mathrm{C}}$ \\
Day 50 & $0.12 \pm 0.01^{\mathrm{a}, \mathrm{E}}$ & $0.08 \pm 0.01^{\mathrm{b}, \mathrm{E}}$ & $0.09 \pm 0.01^{\mathrm{ab}, \mathrm{D}}$ & $0.37 \pm 0.01^{\mathrm{c}, \mathrm{D}}$ \\
Day 60 & $0.04 \pm 0.02^{\mathrm{ab}, \mathrm{F}}$ & $0.07 \pm 0.01^{\mathrm{a}, \mathrm{E}}$ & $0.03 \pm 0.01^{\mathrm{b}, \mathrm{E}}$ & $0.16 \pm 0.01^{\mathrm{c}, \mathrm{E}}$ \\
\hline
\end{tabular}

Legend: ${ }^{1}$ Abbreviations: $\mathrm{BE}$ - Boletus edulis; $\mathrm{CaC}$-Cantharellus cibarius; $\mathrm{CrC}-$ Craterellus cornicupioides; $\mathrm{C}$ - control. Notes: Values are mean \pm standard deviation. Means in the same column with different capital letters (A-F) and means in the same row with different lowercase letters $(\mathrm{a}-\mathrm{c})$ are significantly different $(\mathrm{p}<0.05)$

\section{Oxidative changes in frankfurters during cold storage as measured by TBARs assay}

The TBARs assay is one of the most frequent methods used for determining the degree of secondary oxidative changes on lipids in meat and meat products (Sojic et al., 2017). On storage day 1 , TBARs values for frankfurters with mushrooms were significantly lower in comparison to the control frankfurters (Table 4). This was most likely the consequence of the presence of phenolics in the mushrooms, mixtures that are mainly responsible for the antioxidant activity of many plants (Elmastas et al., 2007). Our TBARs assay results were in accordance with the literature data for a similar type of meat product (Hwang et al., 2015). Additionally, on all days of examination, the incorporation of mushroom decoctions in $\mathrm{T} 1$ and $\mathrm{T} 2$ frankfurters resulted in significantly lower TBARs values than was found in control frankfurters without mushroom decoction. Relative to the control group, frankfurters with the added mushroom decoctions had up to several times lower TBARs values in some cases. It should be mentioned that all TBARs values were less than 1, the value that Ockerman (1985) found to be the limit for the formation of rancidity in meat products.

Throughout frankfurter storage, trends of increasing and then decreasing TBARs values were noticed. We suggest the decline in TBARs values could be attributed to the creation of MDA, an intermediate product; until a certain point, the rate of MDA creation was higher than the rate of its disappearance, and thereafter, the reverse was true. Thus, the disappearance rate overshot the rate of creation, and hence, TBARs values declined (Bhattacharya et al., 1988). Similarly, according to Jamora and Rhee (2002), MDA formed during meat product storage might be subjected to intermolecular reactions (polymerization) and reactions with other constituents, especially amino acids/proteins. Since we used mushroom decoction, which is a complex of polysaccharides, proteins, peptides, and free amino acids, it is very likely that polymerization occurred. Therefore, the MDA disappearance (loss) rate during storage can be higher than the rate of formation by lipid oxidation.

\section{Conclusion}

The mushroom decoctions used in this study expressed measurable antioxidative effects in the prepared frankfurters. We believe mushroom decoctions show potential and should be considered as a natural replacement of the commercial antioxidants in this kind of meat product. Further research is needed to evaluate the overall quality of frankfurters with added mushroom decoction, to be sure that mushroom addition does not have a detrimental effect on the quality and safety parameters of the final product. 


\title{
Antioksidativna aktivnost gljiva in vitro i u frankfurterima
}

\author{
Saša Novaković, Ilija Đekić, Anita Klaus, Jovana Vunduk, Vesna Đorđević, Vladimir Tomović, \\ Branislav Šojić, Sunčica Kocić-Tanackov, Igor Tomašević
}

A p s t r a k t: Ispitivane su antioksidativne karakteristike dekokta vrganja (Boletus edulis), lisičarke (Cantharellus cibarius) $i$ crne trube (Craterellus cornicupioides) i uticaj dodatka gljiva na ukupni sadržaj fenolnih komponenti i stepen sekundarnih oksidativnih promena na mastima u frankfurterima. Umerena antioksidaivna aktivnost dobijena je korišćenjem DPPH metode prilikom testiranja dekokta gljiva in vitro. Korišćenjem konjugen dienske metode, umerena antioksidativna aktivnost postignuta je sa dekoktima vrganja (Boletus edulis) i crne trube (Craterellus cornicupioides), dok je sa lisičarkom (Cantharellus cibarius) taj efekat bio slab. Konstantne količine fenolnih kiselina dobijene su u frankfurterima sa dodatkom vrganja (Boletus edulis), dok je oksidacija lipida prilikom svakog testiranog dana bila nekoliko puta manja u poređenju sa kontrolnom grupom frakfurtera, tokom dva meseca skladištenja u frižideru. Generalno, ove gljive mogu biti korišćene kao prirodni antioksidansi kako bi ometali hemijske produkte kvara i produžili rok trajanja kuvanih svinjskih kobasica.

Ključne reči: Antioksidanti, prirodni ekstrakti, održivost, vrganji, fenoli.

Disclosure statement: No potential conflict of interest was reported by the authors.

\section{References}

Abdullah, N., Ismail, S. M., Aminudin, N., Shuib, A. S. \& Lau, B. F. (2012). Evaluation of selected culinary-medicinal mushrooms for antioxidant and ACE inhibitory activities. Evidence-Based Complementary and Alternative Medicine, 2012.

Ahn, J., Grun, I. U. \& Mustapha, A. (2004). Antimicrobial and antioxidant activities of natural extracts in vitro and in ground beef. Journal of Food Protection, 67(1), 148-155. doi:10.4315/0362-028x-67.1.148

Annegowda, H. V., Bhat, R., Tze, L. M., Karim, A. A. \& Mansor, S. M. (2013). The free radical scavenging and antioxidant activities of pod and seed extract of Clitoria fairchildiana (Howard) - an underutilized legume. Journal of Food Science and Technology, 50(3), 535-541. doi:10.1007/s13197-011-0370-8

Bhattacharya, M., Hanna, M. \& Mandigo, R. (1988). Lipid oxidation in ground beef patties as affected by time-temperature and product packaging parameters. Journal of Food Science, 53(3), 714-717.

Botterweck, A., Verhagen, H., Goldbohm, R., Kleinjans, J. \& Van den Brandt, P. (2000). Intake of butylated hydroxyanisole and butylated hydroxytoluene and stomach cancer risk: results from analyses in the Netherlands cohort study. Food and Chemical Toxicology, 38(7), 599-605.

Chirinang, P. \& Intarapichet, K.-O. (2009). Amino acids and antioxidant properties of the oyster mushrooms, Pleurotus ostreatus and Pleurotus sajor-caju. Science Asia 35(2009), 326-331.

Costa-Lima, B. R. C., Canto, A. C. V. C. S., Suman, S. P., Conte-Junior, C. A., Silveira, E. T. F. \& Silva, T. J. P. (2014). Sex-specific effect of ractopamine on quality attributes of pork frankfurters. Meat Science, 96(2, Part A), 799-805. doi:https://doi.org/10.1016/j.meatsci.2013.10.001
Deda, M. S., Bloukas, J. G. \& Fista, G. A. (2007). Effect of tomato paste and nitrite level on processing and quality characteristics of frankfurters. Meat Science, 76(3), 501-508. doi:https://doi.org/10.1016/j.meatsci.2007.01.004

Djekic, I., Vunduk, J., Tomasevic, I., Kozarski, M., Petrovic, P., Niksic, M., Pudja, P. \& Klaus, A. (2017a). Application of quality function deployment on shelf-life analysis of Agaricus bisporus Portobello. LWT, 78, 82-89. doi:https://doi.org/10.1016/j.lwt.2016.12.036

Djekic, I., Vunduk, J., Tomasevic, I., Kozarski, M., Petrovic, P., Niksic, M., Pudja, P. \& Klaus, A. (2017b). Total quality index of Agaricus bisporus mushrooms packed in modified atmosphere. Journal of the Science of Food Agriculture 97(9), 3013-3021.

Elmastas, M., Isildak, O., Turkekul, I. \& Temur, N. (2007). Determination of antioxidant activity and antioxidant compounds in wild edible mushrooms. Journal of Food Composition Analysis, 20(3-4), 337-345.

Fernández-López, J., Lucas-González, R., Viuda-Martos, M., Sayas-Barberá, E., Navarro, C., Haros, C. M. \& Pérez-Álvarez, J. A. (2019). Chia (Salvia hispanica L.) products as ingredients for reformulating frankfurters: Effects on quality properties and shelf-life. Meat Science.

Hayes, J., Stepanyan, V., Allen, P., O'Grady, M. \& Kerry, J. (2011). Evaluation of the effects of selected plant-derived nutraceuticals on the quality and shelf-life stability of raw and cooked pork sausages. LWT - Food Science Technology, 44(1), 164-172.

Hirano, R., Sasamoto, W., Matsumoto, A., Itakura, H., Igarashi, O. \& Kondo, K. (2001). Antioxidant ability of various flavonoids against DPPH radicals and LDL oxidation. Journal of Nutritional Science and Vitaminology, 47(5), 357-362. 
Huang, D., Ou, B. \& Prior, R. L. (2005). The chemistry behind antioxidant capacity assays. Journal of Agricultural and Food Chemistry, 53(6), 1841-1856. doi:10.1021/ jf030723c

Hwang, K.-E., Kim, H.-W., Song, D.-H., Kim, Y.-J., Ham, Y.K., Lee, J.-W., Choi, Y.-S. \& Kim, C.-J. (2015). Effects of antioxidant combinations on shelf stability of irradiated chicken sausage during storage. Radiation Physics and Chemistry, 106, 315-319. doi:https://doi.org/10.1016/j. radphyschem.2014.08.014

Isabelle, M., Lee, B. L., Lim, M. T., Koh, W.-P., Huang, D. \& Ong, C. N. (2010). Antioxidant activity and profiles of common vegetables in Singapore. Food Chemistry, 120(4), 993-1003.

Jamora, J. \& Rhee, K. (2002). Storage stability of extruded products from blends of meat and nonmeat ingredients: Evaluation methods and antioxidative effects of onion, carrot, and oat ingredients. Journal of Food Science, 67(5), 1654-1659.

Lee, Y.-L., Huang, G.-W., Liang, Z.-C. \& Mau, J.-L. (2007). Antioxidant properties of three extracts from Pleurotus citrinopileatus. LWT - Food Science and Technology, 40(5), 823-833. doi:https://doi.org/10.1016/j.lwt.2006.04.002

Lingnert, H., Vallentin, K. \& Eriksson, C. (1979). Measurement of antioxidative effect in model system. Journal of Food Processing Preservation, 3(2), 87-103.

Liu, Y.-T., Sun, J., Luo, Z.-Y., Rao, S.-Q., Su, Y.-J., Xu, R.-R. \& Yang, Y.-J. (2012). Chemical composition of five wild edible mushrooms collected from Southwest China and their antihyperglycemic and antioxidant activity. Food and Chemical Toxicology, 50(5), 1238-1244. doi:https:// doi.org/10.1016/j.fct.2012.01.023

Mau, J.-L., Tsai, S.-Y., Tseng, Y.-H. \& Huang, S.-J. (2005). Antioxidant properties of hot water extracts from Ganoderma tsugae Murrill. LWT - Food Science and Technology, 38(6), 589-597. doi:https://doi.org/10.1016/j. lwt.2004.08.010

Morrissey, P. A., Sheehy, P. J. A., Galvin, K., Kerry, J. P. \& Buckley, D. J. (1998). Lipid stability in meat and meat products. Meat Science, 49, S73-S86. doi:https://doi. org/10.1016/S0309-1740(98)90039-0

Naveena, B. M., Vaithiyanathan, S., Muthukumar, M., Sen, A. R., Kumar, Y. P., Kiran, M., Shaju, V. A. \& Chandran, K. R. (2013). Relationship between the solubility, dosage and antioxidant capacity of carnosic acid in raw and cooked ground buffalo meat patties and chicken patties. Meat Science, 95(2), 195-202. doi:https://doi. org/10.1016/j.meatsci.2013.04.043

Ockerman, H. W. (1985). Quality control of post-mortem muscle tissue. Dept. of Animal Science, Ohio State University.

Öztürk, M., Aydoğmuş-Öztürk, F., Duru, M. E. \& Topçu, G. (2007). Antioxidant activity of stem and root extracts of Rhubarb (Rheum ribes): An edible medicinal plant. Food Chemistry, 103(2), 623-630.
Özvural, E. B. \& Vural, H. (2011). Grape seed flour is a viable ingredient to improve the nutritional profile and reduce lipid oxidation of frankfurters. Meat Science, 88(1), 179-183. doi:https://doi.org/10.1016/j.meatsci.2010.12.022

Palacios, I., Lozano, M., Moro, C., D’Arrigo, M., Rostagno, M. A., Martínez, J. A., García-Lafuente, A., Guillamón, E. \& Villares, A. (2011). Antioxidant properties of phenolic compounds occurring in edible mushrooms. Food Chemistry, 128(3), 674-678. doi:https://doi. org/10.1016/j.foodchem.2011.03.085

Puttaraju, N. G., Venkateshaiah, S. U., Dharmesh, S. M., Urs, S. M. N. \& Somasundaram, R. (2006). Antioxidant activity of indigenous edible mushrooms. Journal of Agricultural and Food Chemistry, 54(26), 9764-9772. doi:10.1021/jf0615707

Ribas-Agusti, A., Gratacós-Cubarsí, M., Sárraga, C., Guàrdia, M. D., García-Regueiro, J.-A. \& Castellari, M. (2014). Stability of phenolic compounds in dry fermented sausages added with cocoa and grape seed extracts. $L W T$ - Food Science Technology 57(1), 329-336.

Sachindra, N., Sakhare, P., Yashoda, K. \& Rao, D. N. (2005). Microbial profile of buffalo sausage during processing and storage. Food Control, 16(1), 31-35.

Skerget, M., Kotnik, P., Hadolin, M., Hras, A. R., Simonic, M. \& Knez, Z. (2005). Phenols, proanthocyanidins, flavones and flavonols in some plant materials and their antioxidant activities. Food Chemistry, 89(2), 191-198. doi:https://doi.org/10.1016/i.foodchem.2004.02.025

Sojic, B., Tomovic, V., Jokanovic, M., Ikonic, P., Dzinic, N., Kocic-Tanackov, S., Popovic, L., Tasic, T., Savanovic, J. \& Sojic, N. Z. (2017). Antioxidant activity of Juniperus communis L. essential oil in cooked pork sausages. Czech Journal of Food Sciences, 35(3), 189-193.

Tsai, S.-Y., Tsai, H.-L. \& Mau, J.-L. (2007). Antioxidant properties of Agaricus blazei, Agrocybe cylindracea, and Boletus edulis. LWT - Food Science Technology 40(8), 1392-1402.

Van Ba, H., Seo, H.-W., Cho, S.-H., Kim, Y.-S., Kim, J.-H., Ham, J.-S., Park, B. Y. \& Pil Nam, S. (2016). Antioxidant and anti-foodborne bacteria activities of shiitake by-product extract in fermented sausages. Food Control, 70, 201-209. doi:https://doi.org/10.1016/j.foodcont.2016.05.053

Vunduk, J., Klaus, A., Kozarski, M., Petrovic, P., Zizak, Z., Niksic, M. \& Van Griensven, L. J. L. D. J. I. j. o. m. m. (2015). Did the Iceman know better? screening of the medicinal properties of the birch polypore medicinal mushroom, Piptoporus betulinus (Higher Basidiomycetes). 17(12).

Yılmaz, İ., Şimşek, O. \& Işıklı, M. (2002). Fatty acid composition and quality characteristics of low-fat cooked sausages made with beef and chicken meat, tomato juice and sunflower oil. Meat Science, 62(2), 253-258. doi:https:// doi.org/10.1016/S0309-1740(01)00255-8 